\title{
Enhanced elementary sulfur recovery with sequential sulfate-reducing, denitrifying sulfide-oxidizing processes in a cylindrical-type anaerobic baffled reactor
}

\author{
Cong Huang ${ }^{\mathrm{a}, 1}$, Youkang Zhao ${ }^{\mathrm{a}, 1}$, Zhiling $\mathrm{Li}^{\mathrm{a}}$, Ye Yuan ${ }^{\mathrm{a}}$, Chuan Chen ${ }^{\mathrm{a}}$, Wenbo Tan ${ }^{\mathrm{a}}$, Shuang Gao ${ }^{\mathrm{a}}$, \\ Lingfang Gao ${ }^{\mathrm{b}}$, Jizhong Zhou ${ }^{\mathrm{c}, \mathrm{d}}$, Aijie Wang ${ }^{\mathrm{a}, \mathrm{b}, *}$
}

a State Key Laboratory of Urban Water Resource and Environment, Harbin Institute of Technology, Harbin 150090, PR China

${ }^{\mathrm{b}}$ Key Laboratory of Environmental Biotechnology, Research Center for Eco-Environmental Sciences, Chinese Academy of Sciences, Beijing 100085, PR China

${ }^{\mathrm{c}}$ Institute for Environmental Genomics, Department of Microbiology and Plant Biology, University of Oklahoma, Norman, OK 73019, USA

d Earth Science Division, Lawrence Berkeley National Laboratory, Berkeley, CA 94270, USA

\section{H I G H L I G H T S}

- Simultaneous removals of $\mathrm{SO}_{4}{ }^{2-}$, $\mathrm{NO}_{3}{ }^{-}$and $\mathrm{COD}$ and recovery of elemental sulfur in ABR.

- Sulfate reduction and denitrifying sulfide removal were preceded sequentially.

- A high elemental sulfur recovery rate was obtained with $\mathrm{SO}_{4}{ }^{2-}-\mathrm{S} / \mathrm{NO}_{3}{ }^{-}-\mathrm{N}$ ratio of 5:5.

- Bacterial community analysis was conducted associated with SR and DSR processes.

- DsrB gene and aprA gene were abundant in SR and DSR units, respectively.

\section{A R T I C L E I N F O}

\section{Article history:}

Received 5 March 2015

Received in revised form 26 April 2015

Accepted 27 April 2015

Available online 12 May 2015

\section{Keywords:}

Cylindrical-type ABR

Sulfate reduction

Nitrate reduction

Elemental sulfur recovery

Microbial communities analysis
G R A P H I C A L A B S T R A C T

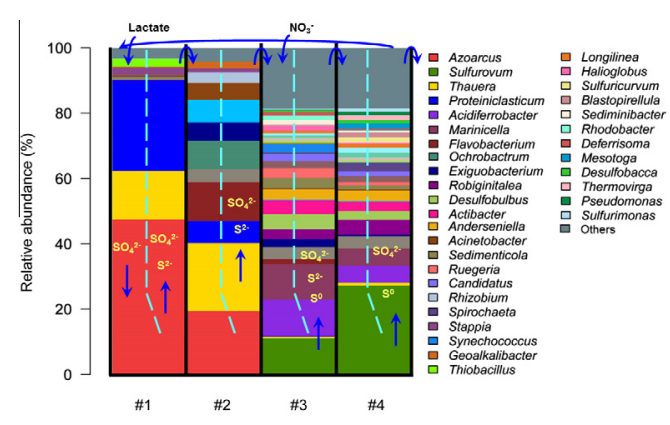

\begin{abstract}
A B S T R A C T
Simultaneous removal of $\mathrm{COD}, \mathrm{SO}_{4}^{2-}$ and $\mathrm{NO}_{3}^{-}$and recovery of elemental sulfur $\left(\mathrm{S}^{0}\right)$ were evaluated in a four-compartment anaerobic baffled reactor $(A B R)$ with separated functional units of sulfate reduction (SR) and denitrifying sulfide removal (DSR). Optimal $\mathrm{SO}_{4}^{2-}-\mathrm{S} / \mathrm{NO}_{3}^{-}-\mathrm{N}$ ratio was evaluated as 5:5, with a substantial improvement of $\mathrm{S}^{0}$ recovery maintained at $79.1 \%$, one of the highest level ever reported; meanwhile, removal rates of $\mathrm{COD}, \mathrm{SO}_{4}^{2-}$ and $\mathrm{NO}_{3}^{-}$were approached at $71.9 \%, 92.9 \%$ and $98.6 \%$, respectively. Nitrate served as a key factor to control the shift of SR and DSR related populations, with the possible involvement of Thauera sp. during SR and Sulfurovum sp. or Acidiferrobacter sp. during DSR, respectively. DsrB and aprA genes were the most abundant during SR and DSR processes, respectively. Cylindrical-type $A B R$ with the improved elemental sulfur recovery was recommended to deal with sulfate and nitrate-laden wastewater under the optimized $\mathrm{SO}_{4}^{2-} / \mathrm{NO}_{3}^{-}$ratio.
\end{abstract}

(c) 2015 Published by Elsevier Ltd.

* Corresponding author at: State Key Laboratory of Urban Water Resource and Environment, Harbin Institute of Technology, Harbin 150090, PR China. Tel.: +86 451 86282195.

E-mail address: waj0578@hit.edu.cn (A. Wang).

${ }^{1}$ Cong Huang and Youkang Zhao contributed equally to this work. 


\section{Introduction}

Sulfate and nitrate-laden wastewater generated from lot of industrial processes, such as pulp production, pharmacy, and petrochemical industry, constituted the serious threatens to human health and eco-systematic safety (Lens et al., 2003; Banu et al., 2008). Effective removal of sulfate and nitrate by application of microorganisms played crucial roles during wastewater treatment processes (Hao et al., 2014; Lu et al., 2014). Meanwhile, elemental sulfur, phosphorus and other nutrient recovery from wastewater are the hot research field during resource recovery processes (Raj et al., 2013; Yuan et al., 2014).

Conventional biological approach to completely remove the toxicity of sulfate-laden wastes consisted of two processes, sulfate reduction to sulfide by sulfate-reducing bacteria (SRB) and sulfide further oxidation to sulfur $\left(\mathrm{S}^{0}\right)$ by sulfide oxidation bacteria (SOB) (Wang et al., 2005). Recent studies found SOB could utilize nitrate as an electron acceptor during sulfide oxidation (denitrifying sulfide removal process, DSR) (Chen et al., 2008); studies on the simultaneous removal of organic carbon, sulfite and nitrate were conducted in either stirred tank reactors (CSTR) or expanded granular sludge bed (EGSB) reactor, which achieved a rather high recovery rate of $S^{0}(>90 \%)$ (Chen et al., 2009).

However, since SRB and SOB involved in diverse environmental niches, the integration of SRB and SOB reactors faced difficulty of the low $S^{0}$ conversion rate (Xu et al., 2012; Yuan et al., 2014). Xu et al. (2013) reported the intense bacterial competition during DSR process, which probably inhibited SOB and resulted in a low $S^{0}$ recovery rate. Therefore, proceeding of removal of organic carbon, sulfate and nitrate and simultaneous recovery of $S^{0}$ in integrated systems remained a technical challenge. Xu et al. (2012) attempted to introduce the limited quantity of DO into EGSB reactor, and found the limited quantity of DO stimulated activities of SOB but did not inhibit those of SRB, which achieved a rather high $S^{0}$ recovery rate of $71.8 \%$. However, the precise control of DO level within this very narrow window (DO range of $0.10-0.12 \mathrm{mg} \mathrm{L}^{-1}$ ) remains a technical difficulty requiring additional energy and cost.

Therefore, to obtain the high $S^{0}$ recovery rate from sulfate, separation of the sulfate reduction (SR) from DSR process is the key process to avoid the bacterial competition and guarantee the SOB activity. The anaerobic baffled reactor (ABR) with the separated reaction units connected in series possesses superiority in segregation of functional bacteria, compared with other anaerobic reactors (Uyanik et al., 2002; Zhu et al., 2008). Previously, some studies had reported the removal of sulfate and nitrate contained wastewater in ABR systems (Barber and Stuckey, 2000; Plumb et al., 2001), but up to now, there is no information on removals of organic carbon, nitrate and $\mathrm{SO}_{4}^{2-}$ for the $\mathrm{S}^{0}$ recovery in ABR system.

The objective of this study was to demonstrate the feasibility of $S^{0}$ recovery during the sequential removal of organic matter, sulfate and nitrate in an ABR system with a separated functional unit of SR and DSR. The optimized $\mathrm{SO}_{4}^{2-}-\mathrm{S} / \mathrm{NO}_{3}^{-}-\mathrm{N}$ ratio was regulated to guarantee the high $\mathrm{S}^{0}$ recovery rate. The molecular analysis on microbial community and functional genes was conducted to further investigate the interplays of functional populations and reaction mechanism. To the authors' best knowledge, this is the first study to describe the bioconversion of sulfate to $S^{0}$ coupled with the removal of organic matter and nitrate in ABR system.

\section{Methods}

\subsection{Bioreactor configuration and operation conditions}

Schematic of the applied ABR configuration were shown in Fig. 1. ABR system was cylindrical form (radius of $10 \mathrm{~cm}$ ) and made

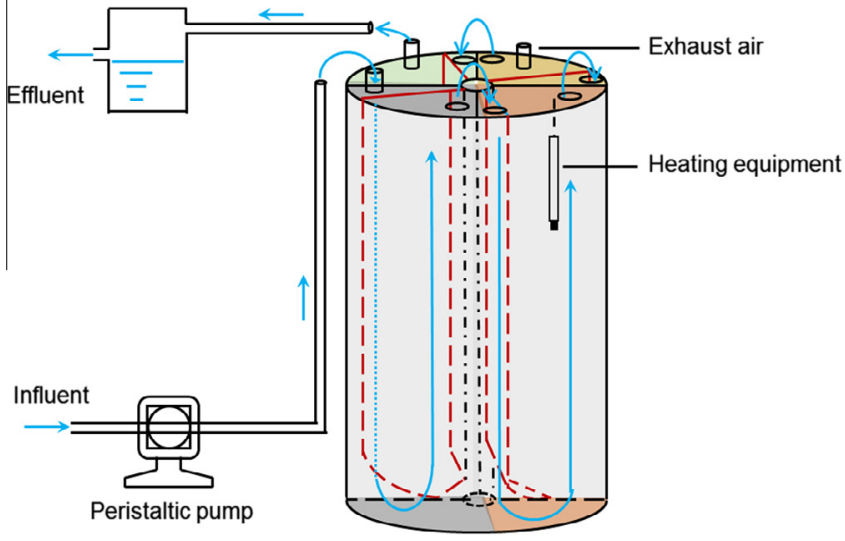

Fig. 1. Schematic diagram of the applied pilot-scale anaerobic baffled reactor (ABR).

of plexiglass, with four equal-volume discrete compartments and a total volume of $9.6 \mathrm{~L}$. The four compartments were divided into two functional units, SR unit (compartment \#1 and \#2) and DSR unit (compartment \#3 and \#4). The flow started from influent of compartment \#1 and sequentially passed through compartment \#2 and \#3 to \#4 ultimately. In each compartment, regions of downcomer and upcomer were separated by a vertical baffle, with an angle of $45^{\circ}$ at the bottom part to confirm the sufficient contact of wastewater and sludge. The volume ratio of upcomer and downcomer was 5:1. Peristaltic pumps were used to control the influent and effluent ratio, with a reflux ratio of 5:1. ABR was operated with a fixed HRT of $24 \mathrm{~h}$. Compared with other ABR systems, the cylindrical-type $A B R$ can largely reduce the high load in the first compartment and maintain the fine microbial activity. The above designed ABR has been authorized as a Chinese patent (201310484595.8).

The applied seed sludge was collected from the anaerobic sludge thickener at the WenChang Wastewater Treatment Plant, Harbin, China. The influent concentration $\left(\mathrm{COD} / \mathrm{SO}_{4}^{2-}-\mathrm{S} / \mathrm{NO}_{3}^{-}-\mathrm{N}\right)$ at three stages was shown in Table 1 . The influent $\left(\mathrm{L}^{-1}\right)$ in compartment \#1 contained: $\mathrm{SO}_{4}^{2-}(500 \mathrm{mg})$, sodium lactate (with the COD of $1000 \mathrm{mg}), \mathrm{Ca}^{2+}(25 \mathrm{mg}), \mathrm{Mg}^{2+}(10 \mathrm{mg})$ and trace element. Bicarbonate $\left(1-2 \mathrm{~g} \mathrm{~L}^{-1}\right)$ was employed to maintain the influent $\mathrm{pH}$ of $8.0 \pm 0.3$. The trace element solution was fed into the influent with the detailed composition described by Chen et al. (2009). Nitrate was applied to compartment \#3, with the concentration of $132.2 \mathrm{mg} \mathrm{L}^{-1}, 326.1 \mathrm{mg} \mathrm{L}^{-1}$ and $504.4 \mathrm{mg} \mathrm{L}^{-1}$, at stage I, II and III, respectively. The resulted $\mathrm{S} / \mathrm{N}$ ratios at three stages were $5: 2$, $5: 5$ and 5:8, respectively (Table 1 ).

\subsection{Analytical methods}

Influent and effluent samples (3-10 mL) were collected from inlet and outlet of the reactor and stored in $-4{ }^{\circ} \mathrm{C}$ refrigerator before went for chemical analysis. Samples $(3-10 \mathrm{~mL}$ ) from the middle of the four compartments at steady running state were harvested with a sterilized sample spoon and stored in a $50 \mathrm{~mL}$ sterile plastic test tubes at $-80^{\circ} \mathrm{C}$ before DNA and RNA extraction.

COD was measured according to US standard methods of water and wastewater measurement (APHA, 1998). Sulfide concentration (including $\mathrm{H}_{2} \mathrm{~S}, \mathrm{HS}^{-1}$ and $\mathrm{S}^{2-}$ ) was determined according to the methylene blue method (Trüper and Schlegel, 1964). Concentrations of $\mathrm{SO}_{4}^{2-}, \mathrm{S}_{2} \mathrm{O}_{3}^{2-}, \mathrm{SO}_{3}^{2-}, \mathrm{NO}_{3}^{-}$and $\mathrm{NO}_{2}^{-}$were measured by an ion chromatography (ICS-90A, Dionex, USA) after filtrated with $0.45 \mu \mathrm{m}$ of the millipore filter. A pH/ORP meter (No. FE20, Merrler Toledo, China) was used to determine the $\mathrm{pH}$ and oxidation-reduction potential (ORP) of liquid samples. Production of 
Table 1

Influent condition of the ABR reactor during the running stage I, II and III.

\begin{tabular}{|c|c|c|c|c|c|}
\hline \multirow[t]{2}{*}{ Running stage } & \multirow[t]{2}{*}{ Time (days) } & \multicolumn{2}{|c|}{ Compartment \#1 $1^{\mathrm{a}}$} & \multirow{2}{*}{$\begin{array}{l}\text { Compartment \#3 } \\
\mathrm{NO}_{3}^{-} \\
\left(\mathrm{mg} \mathrm{L}^{-1}\right)\end{array}$} & \multirow{2}{*}{$\begin{array}{l}\mathrm{SO}_{4}^{2-}-\mathrm{S} / \mathrm{NO}_{3}^{-}-\mathrm{N} \text { ratio } \\
(\mathrm{mol} / \mathrm{mol})\end{array}$} \\
\hline & & $\begin{array}{l}\mathrm{COD} \\
\left(\mathrm{mg} \mathrm{L}^{-1}\right)\end{array}$ & $\begin{array}{l}\mathrm{SO}_{4}^{2-}-\mathrm{S} \\
\left(\mathrm{mg} \mathrm{L}^{-1}\right)\end{array}$ & & \\
\hline I & $0-34$ & $1026.6 \pm 82.1^{b}$ & $168.7 \pm 11.4$ & $132.2 \pm 9.8$ & $5: 2$ \\
\hline II & $34-66$ & $1006.7 \pm 123.2$ & $168.2 \pm 12.8$ & $326.1 \pm 7.4$ & $5: 5$ \\
\hline III & $67-100$ & $1011.5 \pm 112.8$ & $167.7 \pm 22.1$ & $504.4 \pm 14.5$ & $5: 8$ \\
\hline
\end{tabular}

a $\mathrm{COD}$ and $\mathrm{SO}_{4}^{2-}$ was added into the influent of compartment \#1 and $\mathrm{NO}_{3}^{-}$was added into the influent of compartment \#3.

b The data was the average measured results from triplicate samples with the standard deviation shown on the right side of " \pm ".

elemental sulfur was calculated according to the following equation (De Graaff et al., 2012): $\left[S^{0}\right]=\left[\right.$ Influent $\left.\mathrm{SO}_{4}^{2-}\right]-[$ Effluent $\mathrm{SO}_{4}^{2-}$ ] - [Effluent $\mathrm{S}_{2} \mathrm{O}_{3}^{2-}$ ] - [Effluent $\mathrm{HS}^{-}$].

\subsection{Molecular characterization of bacterial populations and function genes}

DNA was extracted using the PowerSoil DNA Isolation kit (MoBio Laboratories Inc, USA) according to the manufacturer's instructions. Concentration and purity of extracted DNA were calculated by Nanophotometer (P-class, Implen, German). Bacterial $\mathrm{V} 1-\mathrm{V} 3$ region of $16 \mathrm{~S}$ rRNA gene was amplified using the forward primer 8F ( $5^{\prime}$-AGAGTTTGATCCTGGCTCAG-3') and reverse primer 533R ( $5^{\prime}$-TTACCGCGGCTGCTGGCAC- $\left.3^{\prime}\right)$. The PCR products were purified using GeneJET ${ }^{\mathrm{TM}}$ PCR purification kit (Fermentas, USA) and then went for pyrosequencing on the 454 Genome Sequencer FLX platform. The sequences obtained from 454 pyrosequencing were analyzed by pipelines of Quantitative Insights Into Microbial Ecology (QIIME) software (www.microbio.me/qiime) (Caporaso et al., 2010; Loudon et al., 2014). Taxonomic classification of each phylotype was determined using SILVA rRNA database project with $97 \%$ sequence similarity rate, as suggested by Wang et al. (2007). Species richness for each community was determined by the number of unique operational taxonomic units (OTUs) and potential species was estimated by Shannon's diversity and evenness indices. Venn diagram was generated to represent the unique OTUs of overlapping species. The diversity indices of ShannonWiener, Venn diagram were performed using the software $\mathrm{R}$ (i386 v3.0.3; http://www.r-project.org/). The Shannon index was calculated to estimate community diversity. The Shannon's diversity index is $H^{\prime}=-\sum_{i=1}^{R} p_{i} \log \left(p_{i}\right)$, in which $p_{i}$ is the proportion of individuals belonging to the $i$ th species in the data set of interest. It could be deduced from the formula that tags at low frequencies either from undetermined rare species or from experimental errors contribute little to the Shannon index, because the $p_{i}$ value for rare tags is normally less than $10^{-3}$ for high-throughput sequencing results. The 16S rRNA gene sequences were deposited in the NCBI Sequence Read Archive under the accession number of SRP052221.

Quantitative real-time PCR ( $q$ PCR) was performed on an $\mathrm{ABI}$ 7500TM Real-Time PCR System (Applied Biosystems). The $q$ PCR mixture $(25 \mu \mathrm{L})$ consisted of $1 \times$ SYBR Green $q$ PCR Mix (Tiangen, China), primer sets ( $200 \mathrm{nM}$ each) and about $3 \mathrm{ng}$ of template DNA. The degenerate primers of $d s r B$ (sulfate reduction related functional genes) and aprA (sulfite oxidization related functional genes) were applied with concentration and PCR conditions described in detail by Varon-Lopez et al. (2014). Calibration curves (log DNA concentration versus an arbitrarily set cycle threshold value) for $d s r B$ genes and aprA genes were constructed using serial dilutions of amplicon of single colonies, obtained from setting up the $16 \mathrm{~S}$ rRNA clone library with bacterial consensus primers $(27 \mathrm{f}$ and 1492r) from DNA samples. Gene copy number of the amplicon was calculated by multiplying the molar concentration of the amplicon by Avogadro's constant. Efficiency values determined in this study were 0.97 and 0.95 for the $d s r B$ and $a p r A$ genes, respectively, with an $R^{2}$ value of 0.99 for both genes. The $q$ PCR detection limits for $d s r B$ genes and aprA genes were $1.5 \times 10^{2}$ copies $\mathrm{mL}^{-1}$ and $3.6 \times 10^{3}$ copies $\mathrm{mL}^{-1}$, respectively. The $R^{2}$ of the standard curves obtained by real-time PCR were up to 0.991 and the reaction efficiency was up to $90 \%$. All experiments were performed in triplicates.

\section{Results and discussion}

\section{1. $\mathrm{ABR}$ performance at the different $\mathrm{SO}_{4}^{2-}-\mathrm{S} / \mathrm{NO}_{3}^{-}-\mathrm{N}$ ratios}

The removal of $\mathrm{COD}, \mathrm{NO}_{3}^{-}, \mathrm{SO}_{4}^{2-}$ and the generation of $\mathrm{S}^{0}$ during stage I, II and III were shown in Fig. 2 and Table 2. At stage I with $\mathrm{SO}_{4}^{2-}-\mathrm{S} / \mathrm{NO}_{3}^{-}-\mathrm{N}$ ratio of $5: 2$, the COD removal rate was fluctuated between $50 \%$ and $60 \%$ at the first 10 days, indicating an acclimation process. After 10 days, the removal rates of $\mathrm{COD}$ and $\mathrm{SO}_{4}^{2-}$ were gradually increased to around $64.0 \%$ and $82.8 \%$, respectively (Fig. 2A and Table 1). The removal of $\mathrm{SO}_{4}^{2-}$ was corresponded to SR process, confirmed by the detection of certain amount of sulfide generation as the metabolites. The determined effluent $\mathrm{pH}$ was about 8.5 , so the main form of sulfide was estimated as $\mathrm{S}^{2-}$. Meanwhile, $\mathrm{NO}_{3}^{-}$removal was unstable at the first 15 days, and while $\mathrm{NO}_{3}^{-}$removal was maintained at around $96.8 \%$ after that (Fig. 2B). Correspondingly, the $S^{0}$ generation rate approached to 60.9\% (Fig. 2C; Table 2).

When $\mathrm{SO}_{4}^{2-}-\mathrm{S} / \mathrm{NO}_{3}^{-}-\mathrm{N}$ ratio approached at 5:5 (stage II), a sustaining increase of removal rates of both $\mathrm{COD}$ and $\mathrm{SO}_{4}^{2-}$ was observed, probably caused by the acclimation of SBR after a long term maintenance (Fig. 2A and C). At steady state of stage II, the removal rates of $\mathrm{COD}$ and $\mathrm{SO}_{4}^{2-}$ were kept at $71.9 \%$ and $92.9 \%$, respectively (Table 2). Interestingly, $\mathrm{NO}_{3}^{-}$removal rate was kept at a rather high lever (98.6\%), although the applied $\mathrm{NO}_{3}^{-}$concentration doubled (Fig. 2B; Table 2). A substantial improvement of $\mathrm{S}^{0}$ recovery was observed and maintained at a rather high level of 79.1\% (Fig. 2C), possibly caused by the augmentation of external electron acceptor of $\mathrm{NO}_{3}^{-}$. The fine performance of $\mathrm{S}^{0}$ recovery and removal of $\mathrm{COD}, \mathrm{SO}_{4}^{2-}$ and $\mathrm{NO}_{3}^{-}$indicated at an optimal running stage with the $\mathrm{SO}_{4}^{2-}-\mathrm{S} / \mathrm{NO}_{3}^{-}-\mathrm{N}$ ratio of $5: 5$.

However, when $\mathrm{SO}_{4}^{2-}-\mathrm{S} / \mathrm{NO}_{3}^{-}-\mathrm{N}$ ratio was further improved to 5:8 (stage III), a decrease in sulfate removal rate was observed although COD removal was further improved to $73.7 \%$ (Fig. 2A; Table 2). Meanwhile, $S^{0}$ recovery rate quickly dropped to $60 \%$ within 5 days and in contrast, $\mathrm{NO}_{3}^{-}$removal was maintained at the relative high lever (Fig. 2C; Table 2).

\subsection{Performance in four compartments under $\mathrm{SO}_{4}^{2-}-\mathrm{S} / \mathrm{NO}_{3}^{-}-\mathrm{N}$ ratio of $5: 5$}

As the optimal running results were observed at stage II, the exact performance in SR unit (compartment \#1 and \#2) and DSR unit (compartment \#3 and \#4) were investigated in Table 3. COD 


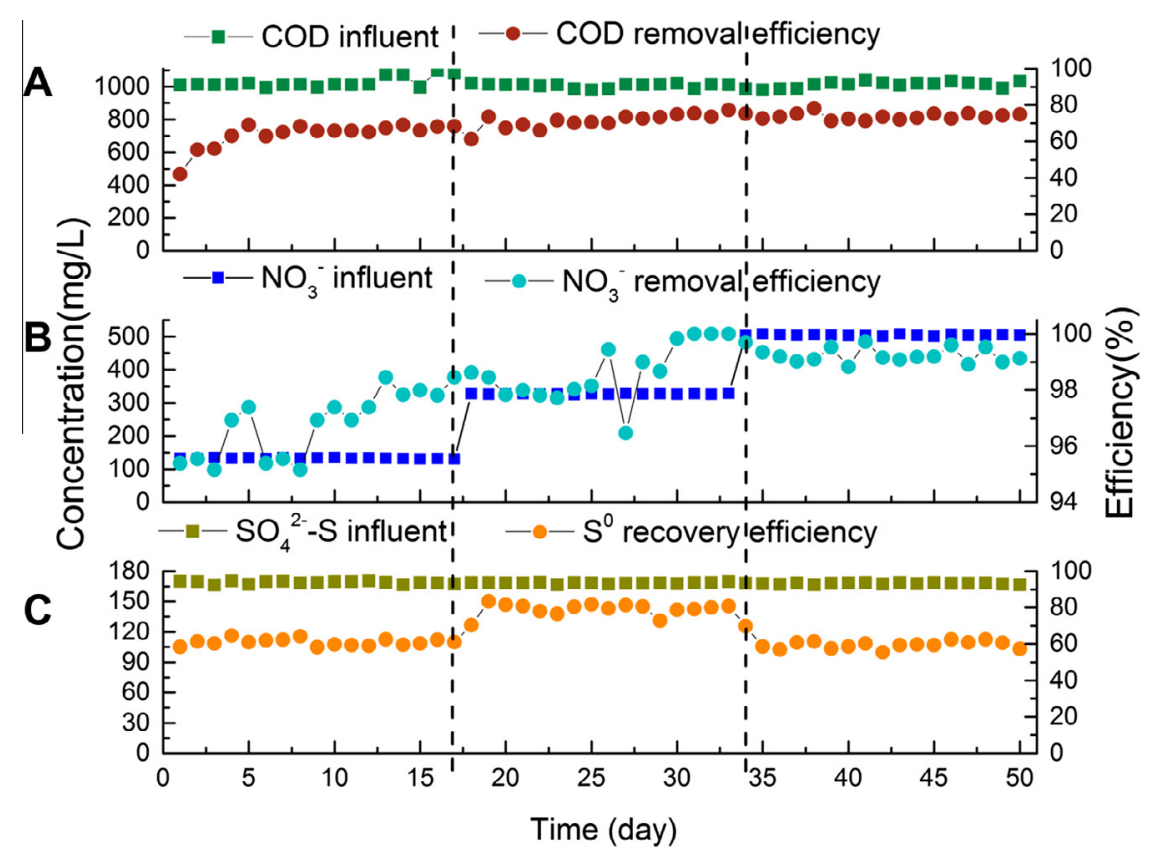

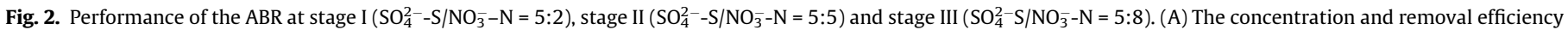
of COD. (B) The concentration change and removal efficiency of $\mathrm{NO}_{3}^{-}$. (C) The concentration of $\mathrm{SO}_{4}^{2-}$ in influent and $\mathrm{S}^{0}$ recovery in effluent.

Table 2

Average results of the removal of $\mathrm{COD}, \mathrm{SO}_{4}^{2-}$ and $\mathrm{NO}_{3}^{-}$and generation of $\mathrm{S}^{0}$ at steady state in $\mathrm{ABR}$ reactor during the running stage I, II and III.

\begin{tabular}{|c|c|c|c|c|c|c|c|c|c|}
\hline \multirow[t]{2}{*}{ Running stage } & \multicolumn{2}{|l|}{ COD } & \multicolumn{2}{|l|}{$\mathrm{NO}_{3}^{-}-\mathrm{N}$} & \multicolumn{2}{|l|}{$\mathrm{SO}_{4}^{2-}-\mathrm{S}$} & \multirow{2}{*}{$\begin{array}{l}\mathrm{S}^{2-} \\
\text { Effluent } \\
\left(\mathrm{mg} \mathrm{L}^{-1}\right)\end{array}$} & \multicolumn{2}{|l|}{$S^{0}$} \\
\hline & $\begin{array}{l}\text { Effluent } \\
\left(\mathrm{mg} \mathrm{L}^{-1}\right)\end{array}$ & Removal rate $^{a}(\%)$ & $\begin{array}{l}\text { Effluent } \\
\left(\mathrm{mg} \mathrm{L}^{-1}\right)\end{array}$ & Removal rate (\%) & $\begin{array}{l}\text { Effluent } \\
\left(\mathrm{mg} \mathrm{L}^{-1}\right)\end{array}$ & Removal rate (\%) & & $\begin{array}{l}\text { Effluent } \\
\left(\mathrm{mg} \mathrm{L}^{-1}\right)\end{array}$ & Generation rate $^{\mathrm{b}}(\%)$ \\
\hline I & $371.8 \pm 12.2^{c}$ & 64.0 & $4.5 \pm 2.0$ & 96.8 & $37.9 \pm 5.4$ & 82.8 & $28.1 \pm 2.5$ & 102.8 & 60.9 \\
\hline II & $289.4 \pm 11.6$ & 71.9 & $4.4 \pm 1.2$ & 98.6 & $27.5 \pm 2.4$ & 92.9 & $7.5 \pm 1.4$ & 133.0 & 79.1 \\
\hline III & $265.9 \pm 30.8$ & 73.7 & $3.8 \pm 0.5$ & 99.2 & $26.7 \pm 3.1$ & 89.9 & $40.3 \pm 0.7$ & 100.7 & 60.1 \\
\hline
\end{tabular}

a Removal rate (\%) was calculated by dividing the effluent concentration with the influent concentration.

b $\mathrm{S}^{0}$ generation rate (\%) was calculated by dividing the effluent concentration of $\mathrm{S}^{0}$ with the concentration of $\mathrm{SO}_{4}^{2-}$ in influent.

c The data was the average results from triplicate samples with the standard deviation shown on the right side of " \pm ".

Table 3

Average concentration of $\mathrm{C}, \mathrm{N}$ and $\mathrm{S}$ in effluent of each compartment at steady state of running stage II.

\begin{tabular}{|c|c|c|c|c|c|c|c|}
\hline & & & $\begin{array}{l}\mathrm{COD} \\
\left(\mathrm{mg} \mathrm{L}^{-1}\right)\end{array}$ & $\begin{array}{l}\mathrm{SO}_{4}^{2-}-\mathrm{S} \\
\left(\mathrm{mg} \mathrm{L}^{-1}\right)\end{array}$ & $\begin{array}{l}\mathrm{NO}_{3}^{-} \\
\left(\mathrm{mg} \mathrm{L}^{-1}\right)\end{array}$ & $\begin{array}{l}\mathrm{S}^{2-} \\
\left(\mathrm{mg} \mathrm{L}^{-1}\right)\end{array}$ & $\begin{array}{l}\mathrm{S}^{0} \\
\left(\mathrm{mg} \mathrm{L}^{-1}\right)\end{array}$ \\
\hline Influent concentration $^{\mathrm{a}}$ & & & $1006.5 \pm 61.2^{\mathrm{b}}$ & $169.2 \pm 5.1$ & $326.0 \pm 18.5$ & - & - \\
\hline \multirow{4}{*}{ Effluent concentration } & SR unit & \#1 & $353.3 \pm 15.6$ & $37.5 \pm 10.2$ & - & $131.5 \pm 24.5$ & $\mathrm{ND}^{\mathrm{c}}$ \\
\hline & & \#2 & $338.2 \pm 11.3$ & $13.3 \pm 6.5$ & - & $140.6 \pm 5.8$ & ND \\
\hline & DSR unit & \#3 & $305.2 \pm 20.6$ & $10.8 \pm 4.4$ & $72.4 \pm 8.6$ & $27.1 \pm 5.6$ & $108.4 \pm 5.2$ \\
\hline & & \#4 & $289.7 \pm 23.2$ & $11.2 \pm 8.4$ & $8.4 \pm 2.5$ & $7.5 \pm 2.5$ & $134.6 \pm 8.5$ \\
\hline
\end{tabular}

a $\mathrm{COD}$ and $\mathrm{SO}_{4}^{2-}$ were added in influent of compartment \#1 and while $\mathrm{NO}_{3}^{-}$was added in influent of compartment \#3.

b The data were the average results from triplicate samples with the standard deviation shown on the right side of " \pm ".

c ND indicated not detected with the measurement methods as described in Section 2.

removal was mostly accomplished in compartment \#1, corresponding to $\mathrm{SO}_{4}^{2-}$ reduction with considerable amount of $\mathrm{S}^{2-}$ generated. In comparison, compartment \#2 undertook much fewer assignments on $\mathrm{COD}$ removal and $\mathrm{SO}_{4}^{2-}$ reduction. No further degradation of $\mathrm{SO}_{4}^{2-}$ and COD seemed to appear in DSR unit (compartments \#3 and \#4). As $\mathrm{NO}_{3}^{-}$was added in influent of compartment \#3 (the initiate of DSR unit), the converted $S^{2-}$ in SR unit was further oxidized to $\mathrm{S}^{0}$ accompanied with $\mathrm{NO}_{3}^{-}$reduction. Both $\mathrm{NO}_{3}^{-}$removal and $\mathrm{S}^{0}$ generation were majorly appeared in compartment \#3.

\subsection{Bacterial diversity analysis under $\mathrm{SO}_{4}^{2-}-\mathrm{S} / \mathrm{NO}_{3}^{-}-\mathrm{N}$ ratio of $5: 5$}

High-throughput sequencing was adopted to determine the abundance and diversity of bacterial populations at SR and DSR units, respectively, as shown in Fig. 3. Over 10,000 sequences were obtained for each sample. The Shannon index was calculated to estimate community diversity. The Shannon's diversity index is $H^{\prime}=-\sum_{i=1}^{R} p_{i} \log \left(p_{i}\right)$, in which $p_{i}$ is the proportion of individuals belonging to the $i$ th species in the data set of interest. It could be deduced from the formula that tags at low frequencies either from 


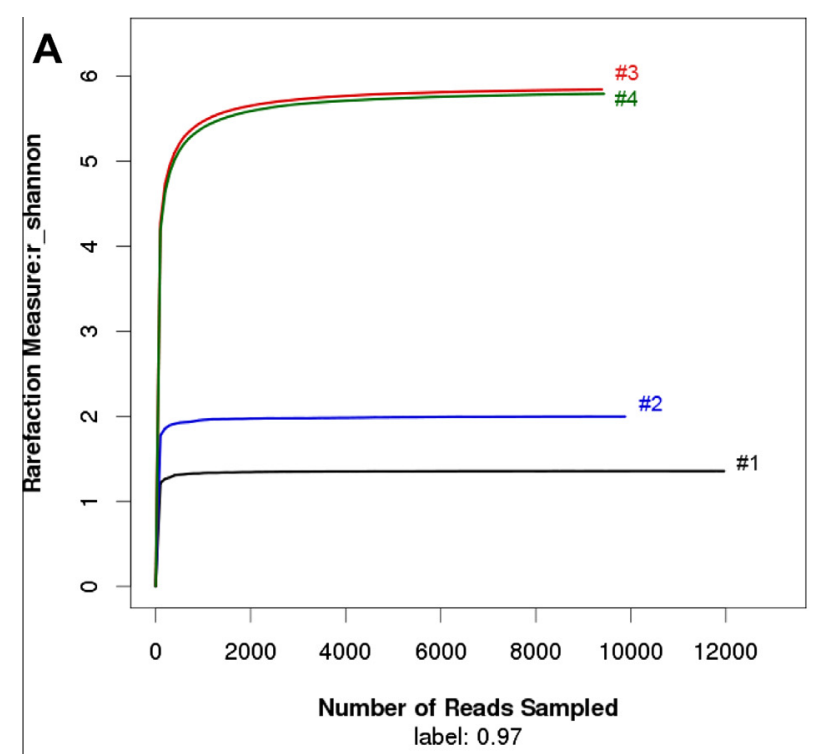

B

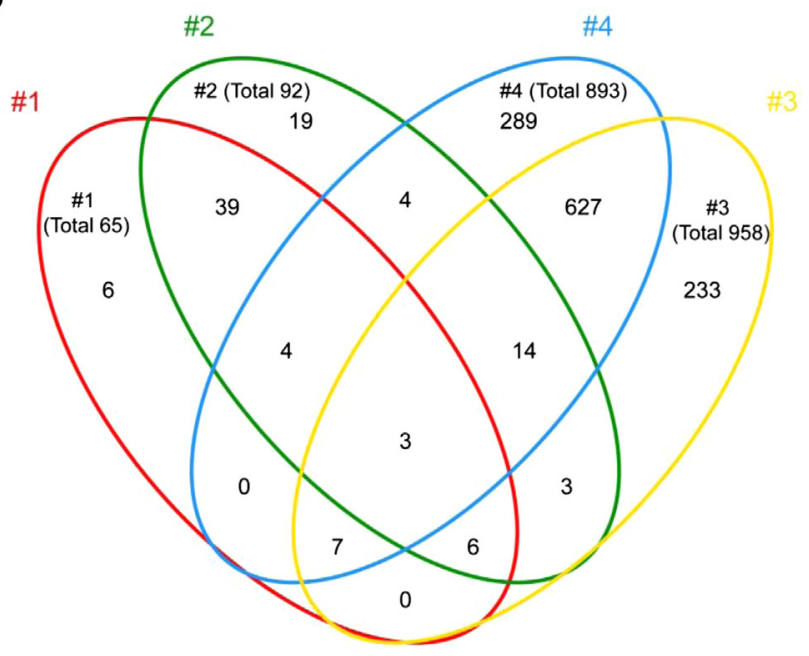

Unique OTUs=2008

Fig. 3. Phylogenetic statistics of the $16 \mathrm{~S}$ rRNA gene sequences of the bacterial communities, in different compartments of the ABR reactor at the steady state of stage II. (A) The Shannon-Wiener curves generated from the operational taxonomic units (OTUs) determined at the four departments. (B) The venn diagram generated from the OTUs determined at the four departments. The number represents the OTUs with the taxonomic identities at genus level with the sequence identity of over $97 \%$.

undetermined rare species or from experimental errors contribute little to the Shannon index, because the $p_{i}$ value for rare tags is normally less than $10^{-3}$ for high-throughput sequencing results. The bacterial communities at SR unit have a relative lower diversity than those in DSR unit, with the Shannon diversity indices of 1.36 and 2 at \#1 and \#2, and 5.84 and 5.79 at \#3 and \#4, respectively (Fig. 3A). Comparing with Shannon diversity indices, the diversity of DSR unit was much more abundant than SR unit, which suggested the occurrence of diverse biochemical reactions.

To stringently analyze the impact of nitrate and independent microbial diversity of ABR reactor. Venn analysis was used to analyze unique OTUs and share the similarity and difference in different community. As the result of Venn analysis, there was a significant change of microbial communities, where only 3 of the total 2008 OTUs were shared in four departments (Fig. 3B). The shared OTUs were Peptostreptococcaceae, Proteiniclasticum, Thauera. A total of 65, 92, 958 and 893 OTUs were found in four compartments. About half of OTUs were shared with each other in both SR units (compartments \#1 and \#2) and DSR units (compartments \#3 and \#4), respectively. The Shannon indices and visual of Venn diagram indicated a distinct impact on microbial community by addition of nitrate.

\subsection{Bacterial community analysis under $\mathrm{SO}_{4}^{2-}-\mathrm{S} / \mathrm{NO}_{3}^{-}-\mathrm{N}$ ratio of $5: 5$}

Fig. 4 showed the bacterial communities in compartments \# 1 to \#4 based on the 454 pyrosequencing analysis. The bacterial community in SR unit was dominated with Azoarcus $(47.5 \%$ and 19.4\% in \#1 and \#2, respectively), Proteiniclasticum (27.6\% and $8.1 \%$ in $\# 1$ and \#2, respectively) and Thauera (14.8\% and $19.5 \%$ in $\# 1$ and \#2, respectively). And while Thiobacillus (2.8\%) was only appeared in \#1, and Flavbacterium (10.7\%) was existed in \#2. Among of them, Azoarcus was able to degrade lactate to $\mathrm{CO}_{2}$ and consume N-compound (Reinhold-Hurek et al., 1993; Mechichi et al., 2002). Thauera would transform $\mathrm{SO}_{4}^{2-}$ to $\mathrm{S}^{2-}$ with organic matters as electron donors and carbon sources (Zhang et al., 2010), which was probably the functional genus in charge of $\mathrm{SO}_{4}^{2-}$ reduction.

Bacteria in DSR unit were much more diverse and majorly consisted of Sulfurovum (11.3\% and $22.4 \%$ in \#1 and \#2, respectively), Acidiferrobacter (10.6\% and $4.9 \%$ in \#3 and \#4, respectively), Marinicella (9.7\% and $4.8 \%$ in \#3 and \#4, respectively) and Desulfobulbus (4.5\% and 3.5\% in \#3 and \#4, respectively). These populations held the capacity of conversion of $\mathrm{S}^{2-}$ to $\mathrm{S}^{0}$, or $\mathrm{NO}_{3}^{-}$ to $\mathrm{N}_{2}$ (Widdel and Pfennig, 1982; Elshahed et al., 2003; Inagaki et al., 2004; Shoji et al., 2014). The introduction of nitrate enriched both sulfide-oxidizing and nitrate-reducing bacteria, which inhibited SRB and attributed to the enhancement of $S^{0}$ reclamation. The dominants of Thauera in SR process and Sulfurovum and Acidiferrobacter in DSR process (Fig. 4) indicated a successful separation of SRB and SOB, which resulted in a high $S^{0}$ recovery accompanied with the removal of $\mathrm{SO}_{4}^{2-}, \mathrm{NO}_{3}^{-}$and COD.

\section{5. qPCR analysis of dsrB and aprA genes under $\mathrm{SO}_{4}^{2-}-\mathrm{S} / \mathrm{NO}_{3}^{-}-\mathrm{N}$ ratio of} $5: 5$

As shown in Fig. 5, dsrB gene was much more abundant than aprA gene in SR unit, with the log value ranging from 27.1 to 21.1 for $d s r B$ and from 6.9 to 8.6 for aprA (copies gram of sludge), respectively. The $\log d s r B / a p r A$ value was 3.9 for compartment $\# 1$ and 2.4 for \#2, respectively. In contrast, the aprA gene was rather higher than $d s r B$ gene, with the $\log$ value ranging from 27.8 to 18.1 for aprA gene and 7.7 to 10.1 for $d s r B$ gene (copies gram of sludge) in DSR unit, respectively. The log $d s r B / a p r A$ value was 0.27 for compartment \#3 and 0.56 for \#4, respectively (Fig. 5). The difference on $d s r B$ and aprA distribution verified the separated function in SR and DSR units. The results on microbial community and functional genes indicated the shift of SRB and SOB took important roles in sulfur reclamation.

\subsection{Discussion}

In this study, a high sulfate to elemental sulfur conversion rate (79.1\%) was obtained by separating SR and DSR functional units, which overcame the technical difficulties brought by the niches difference of SOB and SRB in integrated systems. Previously, several studies have focused on the simultaneous removal of carbon, nitrate and sulfur. Reyes-Avila et al. (2004) applied a CSTR reactor for simultaneous removal of $\mathrm{NO}_{3}^{-}, \mathrm{S}^{2-}$ and COD, with a rather low $S^{0}$ recovery of $0.3 \%$. Krishnakumar et al. (2005) reported the sulfide oxidation by Thiobacillus denitrificans in a reverse fluidized loop 


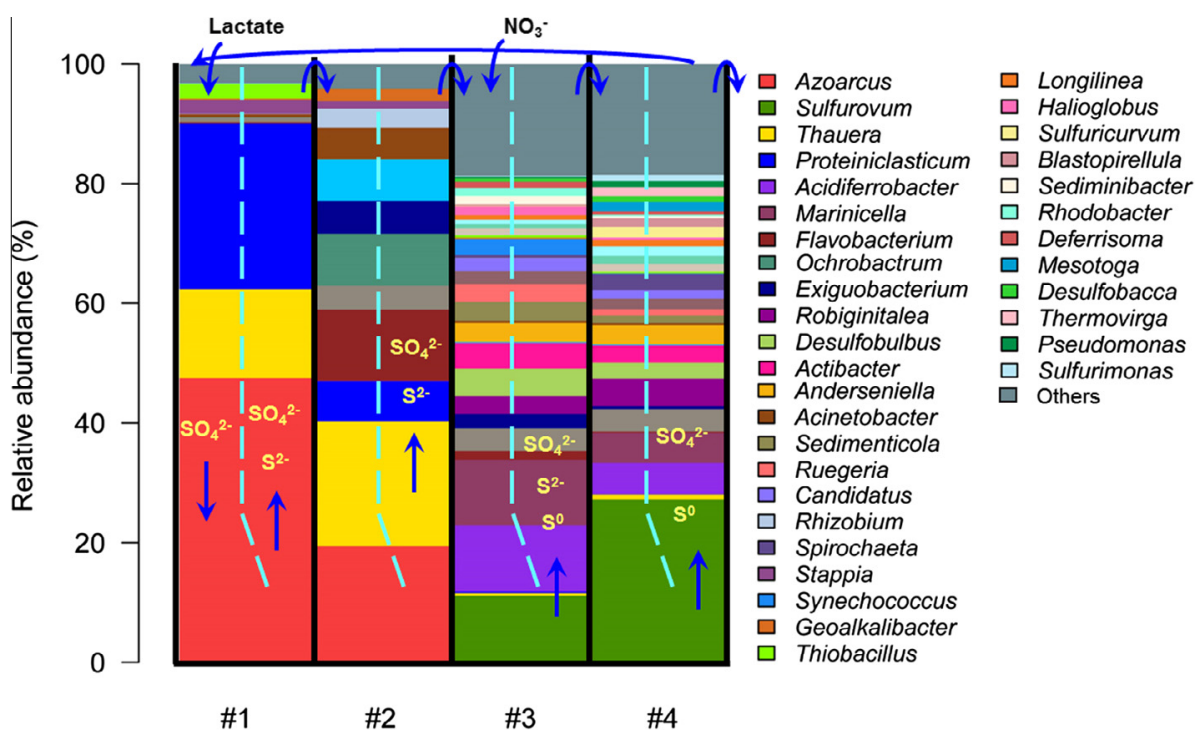

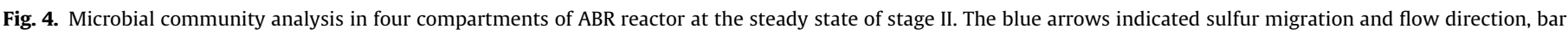

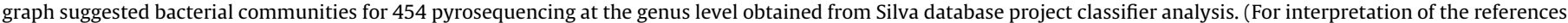
to colour in this figure legend, the reader is referred to the web version of this article.)

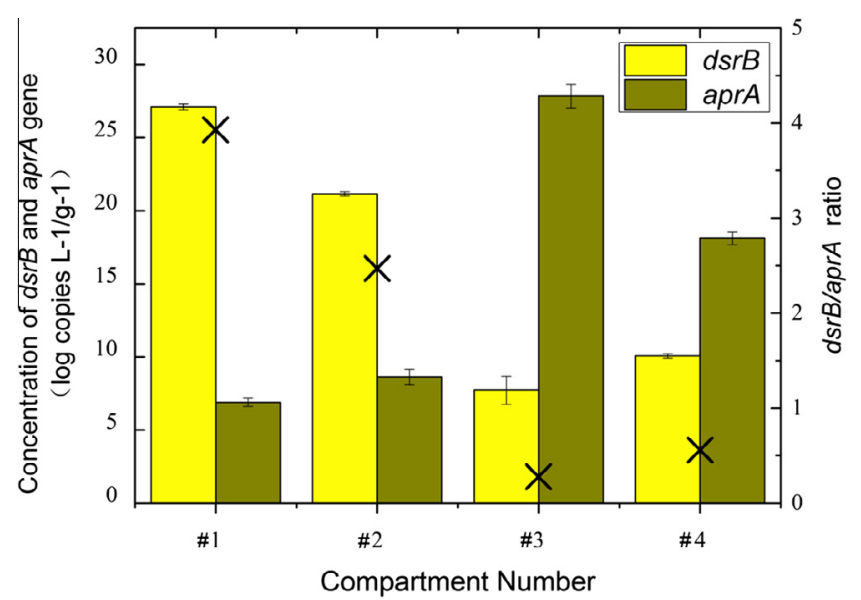

Fig. 5. Abundance of $d s r B$ and aprA gene copies and $d s r B / a p r A$ ratio in compartments \#1 to \#4 at the steady state of stage II.

reactor and revealed that under $\mathrm{pH}$-controlled condition $95 \%$ of the fed sulfide was converted to $S^{0}$. Chen et al. (2008) developed the removal processes of carbon, nitrate and sulfur, which achieved a highest $S^{0}$ recovery rate of $90 \%$ using EGSB reactor. Since the natural existed sulfur was majorly drawn from sulfate reduction, the recovery of $S^{0}$ from sulfate embodied more engineering significance (Show et al., 2013). Xu et al. (2012, 2014) applied micro-aerobic DO into the EGSB reactor with the $S^{0}$ recovery rate of $71.8 \%$, and however, the technical difficulties of precise control of DO level largely reduced the practical application possibility. Yuan et al. (2014) evaluated the tuning parameters to regulate the SR and DSR processes in EGSB reactors and yet, only 60\% of $S^{0}$ recovery was obtained. In sum, the separated SR and DSR processes in ABR system in this study obtained the highest $S^{0}$ recovery rate from sulfate ever reported.

Lactate was proven as the more favorable substrate than hydrogen, methanol, ethanol, and acetate for sulfate reduction (Liamleam and Annachhatre, 2007). Hence, in SR unit, lactate was applied as both electron donor and carbon source $\left(\mathrm{CH}_{3} \mathrm{CHOHCOOH}+0.5 \mathrm{H}_{2} \mathrm{SO}_{4} \rightarrow \mathrm{CH}_{3} \mathrm{COOH}+\mathrm{CO}_{2}+0.5 \mathrm{H}_{2} \mathrm{~S}+\mathrm{H}_{2} \mathrm{O}\right)$; acetate, a sulfate reducing metabolite, can be further utilized as electron donor during SR process $\left(\mathrm{CH}_{3} \mathrm{COO}^{-}+\mathrm{SO}_{4}^{2-} \rightarrow \mathrm{HS}^{-}+\right.$ $2 \mathrm{HCO}_{3}^{-}$). Besides, SRB could use hydrogen generated during lactate fermentation process (i.e. $4 \mathrm{H}_{2}+\mathrm{SO}_{4}^{2-}+\mathrm{H}^{+} \rightarrow \mathrm{HS}^{-}+4 \mathrm{H}_{2} \mathrm{O}$ ) (Liamleam and Annachhatre, 2007). Assuming $\mathrm{COD} / \mathrm{SO}_{4}^{2-}$ ratio of 0.667 and COD/cell ratio of 1.42 (cell formula of $\mathrm{C}_{5} \mathrm{H}_{7} \mathrm{O}_{2} \mathrm{~N}$ ), COD balance was calculated according to the data of influent and effluent (Fig. 3). COD consumed for SR and biomass were $632.1 \mathrm{mg}$ and $26.2 \mathrm{mg}$ (\#1) and $455.2 \mathrm{mg}$ and $18.9 \mathrm{mg}$ (\#2), which took up $26.2 \%$ and $4.6 \%(\# 1)$ and $18.9 \%$ and $1.2 \%$ (\#2) of influent COD, respectively. After subtraction of effluent COD (35.1\% for \#1, 90.2\% for $\# 2$ ), about $19.9 \%$ and $1.5 \%$ of COD were missing in \#1 and \#2, respectively. The missing COD was attributed to the involvement of the other biochemical reactions, like methane generation (i.e. $\mathrm{CH}_{3} \mathrm{COOH} \rightarrow \mathrm{CH}_{4}+4 \mathrm{H}_{2} \mathrm{O}$ ) (Show et al., 2013) or etc.

In compartment \#3 and \#4, $\mathrm{S}^{0}$ generation was proceeded autotrophically by using $\mathrm{S}^{2-}$ as the electron donor and while $\mathrm{NO}_{3}^{-}$was applied as an electron acceptor $\left(\mathrm{S}^{2-}+0.4 \mathrm{NO}_{3}^{-}+1.2 \mathrm{H}_{2} \mathrm{O} \rightarrow\right.$ $\mathrm{S}^{0}+0.2 \mathrm{~N}_{2}+2.4 \mathrm{OH}^{-}$). Assuming all $\mathrm{NO}_{3}^{-}$contributed to DSR process with $\mathrm{NO}_{3}^{-} / \mathrm{S}^{2-}$ ratio of $0.91, \mathrm{NO}_{3}^{-}$mass balance was calculated according to the data of influent and effluent (Fig. 3). $\mathrm{NO}_{3}^{-}$consumed for $\mathrm{S}^{2-}$ oxidation were $247.9 \mathrm{mg}$ and $67.8 \mathrm{mg}$ in \#3 and $\# 4$, respectively, which occupied $31.6 \%$ and $39 \%$ of influent $\mathrm{NO}_{3}^{-}$, respectively. After subtraction of effluent $\mathrm{NO}_{3}^{-}$(22.2\% for \#3, $11.6 \%$ for $\# 4$ ), the balance indicated $41.3 \%$ and $49.4 \%$ of $\mathrm{NO}_{3}^{-}$were missing in \#3 and \#4, respectively. The missing $\mathrm{NO}_{3}^{-}$was probably involved in the other biochemical reactions, such as consumption of COD applying some short-chain acids as electron donor (i.e. $\mathrm{NO}_{3}^{-}+0.63 \mathrm{CH}_{3} \mathrm{COO}^{-}+0.37 \mathrm{CO}_{2} \rightarrow 0.5 \mathrm{~N}_{2}+0.13 \mathrm{H}_{2} \mathrm{O}+1.63 \mathrm{HCO}_{3}^{-}$) (Chen et al., 2009), or $S^{0}$ further reduction to sulfur $\left(\mathrm{S}^{0}+1.2 \mathrm{NO}_{3}^{-}+0.4 \mathrm{H}_{2} \mathrm{O} \rightarrow \mathrm{SO}_{4}^{2-}+0.6 \mathrm{~N}_{2}+0.8 \mathrm{H}^{+}\right)$(An et al., 2010) or $\mathrm{S}^{2-}$ oxidation to $\mathrm{SO}_{4}^{2-}\left(\mathrm{S}^{2-}+1.6 \mathrm{NO}_{3}^{-}+1.6 \mathrm{H}^{+} \rightarrow \mathrm{SO}_{4}^{2-}+0.8 \mathrm{~N}_{2}+\right.$ $0.8 \mathrm{H}_{2} \mathrm{O}$ ) (An et al., 2010).

Comparing the performance of stage II and III, the SRB and SOB community maintain their activity and $\mathrm{SO}_{4}^{2-}$ reduce to $\mathrm{S}^{0}$ as the end product rather than $\mathrm{S}^{2-}$ at $\mathrm{SO}_{4}^{2-}-\mathrm{S} / \mathrm{NO}_{3}^{-}-\mathrm{N}$ ratio was $1: 1$ (in this study). The prominent $S^{0}$ recovery, $C O D$ and nitrate removal require the balance of microbial growth and nutrient transports and the relationship to electron donors. Since $\mathrm{NO}_{3}^{-}$is a strong inhibitor in both growth and activity of SRB (Hao et al., 2014), no sulfate reduction was estimated in \#3 and \#4, confirmed by the much 
lower aprA genes in \#3 and \#4 compared with \#1 and \#2 (Fig. 5). Meanwhile, the addition of $\mathrm{NO}_{3}^{-}$effectively avoided the inhibition of sulfate and nitrate reduction and achieved both the high SR rate and $\mathrm{S}^{0}$ recovery rate. In stage III with $\mathrm{SO}_{4}^{2-}-\mathrm{S} / \mathrm{NO}_{3}^{-}-\mathrm{N}$ ratio was further improved to $5: 8$, the drop in $S^{0}$ recovery and sulfate removal was probably attributed to the application of excess amount of $\mathrm{NO}_{3}^{-}$, which was probably aroused from some other unwanted bio-reactions, such as the $S^{0}$ further reduction to sulfur using the redundant nitrate or $\mathrm{S}^{2-}$ oxidation directly to $\mathrm{SO}_{4}^{2-}$ with the sufficient nitrate.

$\mathrm{SO}_{4}^{2-}-\mathrm{S} / \mathrm{NO}_{3}^{-}-\mathrm{N}$ ratio played an important role in $\mathrm{ABR}$ reactor since it largely affected the $S^{0}$ recovery rate. The microbial analysis on the $\mathrm{SO}_{4}^{2-}-\mathrm{S} / \mathrm{NO}_{3}^{-}-\mathrm{N}$ ratio of 5:5 confirmed nitrate as a key factor to control the shift of SRB and SOB community. SR process appeared in the first and second compartments, confirmed by sulfate-reducing populations (such as Thauera sp. with a functional gene like $d s r B$ ). However, DSR was occurred at the third and fourth compartments, verified by sulfide-oxidizing bacteria (such as Sulfurovum sp. or Acidiferrobacter sp. with the functional gene like aprA). Effective regulation of $\mathrm{SO}_{4}^{2-}-\mathrm{S} / \mathrm{NO}_{3}^{-}-\mathrm{N}$ ratio would realize the functional reaction separation and maximize the activity of SRB and SOB community.

\section{Conclusion}

Here, we depicted for the first time the removal of organic matter, sulfate and nitrate and generation of $S^{0}$ in an ABR with the separated units of SR and DSR, which achieved a high $S^{0}$ recovery rate of $79.1 \%$. The alteration of $\mathrm{SO}_{4}^{2-}-\mathrm{S} / \mathrm{NO}_{3}^{-}-\mathrm{N}$ ratio and description on microbial diversity/functional genes suggested the optimized performance condition in ABR with a benefit of enhancing $S^{0}$ recovery.

\section{Acknowledgements}

We gratefully acknowledge the support by the National High-tech R\&D Program of China (863 Program, Grant No. 2011AA060904), by National Science Foundation for Distinguished Young Scholars of China (Grant No. 51225802), by Science Fund for Creative Research Groups of the National Natural Science Foundation of China (Grant No. 51121062), by National Key Technology Research and Development Program of the Ministry of Science and Technology of China (2010BAC67B02), by the National Natural Science Foundation of China (Grant Nos. 51176037 and 51308147), and by Fundamental Research Funds for Central Universities of China (AUGA5710055514).

\section{References}

An, S., Tang, K., Nemati, M., 2010. Simultaneous biodesulphurization and denitrification using an oil reservoir microbial culture: effects of sulphide loading rate and sulphide to nitrate loading ratio. Water Res. 44 (5), 1531-1541.

APHA, 1998. Standard Methods for the Examination of Water and Wastewater 20th ed. American Public Health Association, Inc., New York, USA.

Banu, J.R., Do, K.-U., Yeom, I.-T., 2008. Effect of ferrous sulphate on nitrification during simultaneous phosphorus removal from domestic wastewater using a laboratory scale anoxic/oxic reactor. World J. Microbiol. Biotechnol. 24 (12), 2981-2986.

Barber, W.P., Stuckey, D.C., 2000. Nitrogen removal in a modified anaerobic baffled reactor (ABR): 1, denitrification. Water Res. 34 (9), 2413-2422.

Caporaso, J.G., Kuczynski, J., Stombaugh, J., Bittinger, K., Bushman, F.D., Costello, E.K., Fierer, N., Pena, A.G., Goodrich, J.K., Gordon, J.I., Huttley, G.A., Kelley, S.T., Knights, D., Koenig, J.E., Ley, R.E., Lozupone, C.A., McDonald, D., Muegge, B.D., Pirrung, M., Reeder, J., Sevinsky, J.R., Tumbaugh, P.J., Walters, W.A., Widmann, J., Yatsunenko, T., Zaneveld, J., Knight, R., 2010. QIIME allows analysis of highthroughput community sequencing data. Nat. Methods 7 (5), 335-336.

Chen, C., Wang, A.J., Ren, N.Q., Kan, H.J., Lee, D.J., 2008. Biological breakdown of denitrifying sulfide removal process in high-rate expanded granular bed reactor. Appl. Microbiol. Biotechnol. 81 (4), 765-770.
Chen, C., Wang, A.J., Ren, N.Q., Lee, D.J., Lai, J.Y., 2009. High-rate denitrifying sulfide removal process in expanded granular sludge bed reactor. Bioresour. Technol. 100 (7), 2316-2319.

De Graaff, M., Klok, J.B.M., Bijmans, M.F.M., Muyzer, G., Janssen, A.J.H., 2012 Application of a 2-step process for the biological treatment of sulfidic spent caustics. Water Res. 46 (3), 723-730.

Elshahed, M.S., Senko, J.M., Najar, F.Z., Kenton, S.M., Roe, B.A., Dewers, T.A., Spear, J.R., Krumholz, L.R., 2003. Bacterial diversity and sulfur cycling in a mesophilic sulfide-rich spring. Appl. Environ. Microbiol. 69 (9), 5609-5621.

Hao, T.-W., Xiang, P.-Y., Mackey, H.R., Chi, K., Lu, H., Chui, H.-K., van Loosdrecht, M.C.M., Chen, G.-H., 2014. A review of biological sulfate conversions in wastewater treatment. Water Res. 65, 1-21.

Inagaki, F., Takai, K., Nealson, K.H., Horikoshi, K., 2004. Sulfurovum lithotrophicum gen. nov., sp. nov., a novel sulfur-oxidizing chemolithoautotroph within the $\varepsilon$ proteobacteria isolated from Okinawa Trough hydrothermal sediments. Int. J. Syst. Evol. Microbiol. 54 (5), 1477-1482.

Krishnakumar, B., Majumdar, S., Manilal, V.B., Haridas, A., 2005. Treatment of sulphide containing wastewater with sulphur recovery in a novel reverse fluidized loop reactor (RFLR). Water Res. 39 (4), 639-647.

Lens, P.N.L., Klijn, R., van Lier, J.B., Lettinga, G., 2003. Effect of specific gas loading rate on thermophilic $(55 \mathrm{C})$ acidifying $(\mathrm{pH} 6)$ and sulfate reducing granular sludge reactors. Water Res. 37 (5), 1033-1047.

Liamleam, W., Annachhatre, A.P., 2007. Electron donors for biological sulfate reduction. Biotechnol. Adv. 25 (5), 452-463.

Loudon, A.H., Woodhams, D.C., Parfrey, L.W., Archer, H., Knight, R., McKenzie, V. Harris, R.N., 2014. Microbial community dynamics and effect of environmental microbial reservoirs on red-backed salamanders (Plethodon cinereus). ISME J. 8 (4), 830-840

Lu, H., Chandran, K., Stensel, D., 2014. Microbial ecology of denitrification in biological wastewater treatment. Water Res. 64, 237-254.

Mechichi, T., Stackebrandt, E., Gad'on, N., Fuchs, G., 2002. Phylogenetic and metabolic diversity of bacteria degrading aromatic compounds under denitrifying conditions, and description of Thauera phenylacetica sp. nov., Thauera aminoaromatica sp. nov., and Azoarcus buckelii sp. nov. Arch. Microbiol. 178 (1), 26-35.

Plumb, J.J., Bell, J., Stuckey, D.C., 2001. Microbial populations associated with treatment of an industrial dye effluent in an anaerobic baffled reactor. Appl. Environ. Microbiol. 67 (7), 3226-3235.

Raj, S.E., Banu, J.R., Kaliappan, S., Yeom, I.-T., Adish Kumar, S., 2013. Effects of sidestream, low temperature phosphorus recovery on the performance of anaerobic/anoxic/oxic systems integrated with sludge pretreatment. Bioresour. Technol. 140, 376-384.

Reinhold-Hurek, B., Hurek, T., Gillis, M., Hoste, B., Vancanneyt, M., Kersters, K., De Ley, J., 1993. Azoarcus gen. nov., nitrogen-fixing proteobacteria associated with roots of kallar grass (Leptochloa fusca (L.) Kunth), and description of two species, Azoarcus indigens sp. nov. and Azoarcus communis sp. nov. Int. J. Syst. Evol. Microbiol. 43 (3), 574-584.

Reyes-Avila, J., Razo-Flores, E.a., Gomez, J., 2004. Simultaneous biological removal of nitrogen, carbon and sulfur by denitrification. Water Res. 38 (14-15), 33133321.

Shoji, T., Sueoka, K., Satoh, H., Mino, T., 2014. Identification of the microbial community responsible for thiocyanate and thiosulfate degradation in an activated sludge process. Process Biochem. 49 (7), 1176-1181.

Show, K.-Y., Lee, D.-J., Pan, X., 2013. Simultaneous biological removal of nitrogensulfur-carbon: recent advances and challenges. Biotechnol. Adv. 31 (4), 409420.

Trüper, H.G., Schlegel, H.G., 1964. Sulphur metabolism in Thiorhodaceae I. Quantitative measurements on growing cells of Chromatium okenii. Anton. Leeuw. Int. J. G. 30 (1), 225-238.

Uyanik, S., Sallis, P.J., Anderson, G.K., 2002. The effect of polymer addition on granulation in an anaerobic baffled reactor (ABR). Part II: compartmentalization of bacterial populations. Water Res. 36 (4), 944-955.

Varon-Lopez, M., Dias, A.C., Fasanella, C.C., Durrer, A., Melo, I.S., Kuramae, E.E., Andreote, F.D., 2014. Sulphur-oxidizing and sulphate-reducing communities in Brazilian mangrove sediments. Environ. Microbiol. 16 (3), $845-855$.

Wang, A.-J., Du, D.-Z., Ren, N.-Q., Van-Groenestijn, J.W., 2005. An innovative process of simultaneous desulfurization and denitrification by Thiobacillus denitrificans. J. Environ. Sci. Health A 40 (10), 1939-1949.

Wang, Q., Garrity, G.M., Tiedje, J.M., Cole, J.R., 2007. Naive Bayesian classifier for rapid assignment of rRNA sequences into the new bacterial taxonomy. Appl. Environ. Microbiol. 73 (16), 5261-5267.

Widdel, F., Pfennig, N., 1982. Studies on dissimilatory sulfate-reducing bacteria that decompose fatty acids II. Incomplete oxidation of propionate by Desulfobulbus propionicus gen. nov., sp. nov. Arch. Microbiol. 131 (4), 360-365.

Xu, X.J., Chen, C., Lee, D.J., Wang, A.J., Guo, W.Q., Zhou, X., Guo, H.L., Yuan, Y., Ren, N.Q., Chang, J.S., 2013. Sulfate-reduction, sulfide-oxidation and elemental sulfur bioreduction process: modeling and experimental validation. Bioresour. Technol. 147, 202-211.

Xu, X.J., Chen, C., Wang, A.J., Fang, N., Yuan, Y., Ren, N.Q., Lee, D.J., 2012. Enhanced elementary sulfur recovery in integrated sulfate-reducing, sulfurproducing rector under micro-aerobic condition. Bioresour. Technol. 116, 517-521.

Xu, X.J., Chen, C., Wang, A.J., Yu, H., Zhou, X., Guo, H.L., Yuan, Y., Lee, D.J., Zhou, J. Ren, N.Q., 2014. Bioreactor performance and functional gene analysis of microbial community in a limited-oxygen fed bioreactor for co-reduction 
of sulfate and nitrate with high organic input. J. Hazard. Mater. 278, $250-257$.

Yuan, Y., Chen, C., Liang, B., Huang, C., Zhao, Y.K., Xu, X.J., Tan, W.B., Zhou, X., Gao, S., Sun, D.Z., Lee, D.J., Zhou, J.Z., Wang, A.J., 2014. Fine-tuning key parameters of an integrated reactor system for the simultaneous removal of COD, sulfate and ammonium and elemental sulfur reclamation. J. Hazard. Mater. 269, 56-67.
Zhang, K., Song, L., Dong, X., 2010. Proteiniclasticum ruminis gen. nov., sp. nov., a strictly anaerobic proteolytic bacterium isolated from yak rumen. Int. J. Syst. Evol. Microbiol. 60 (Pt 9), 2221-2225.

Zhu, G.F., Li, J.Z., Wu, P., Jin, H.Z., Wang, Z., 2008. The performance and phase separated characteristics of an anaerobic baffled reactor treating soybean protein processing wastewater. Bioresour. Technol. 99 (17), 8027-8033. 